\title{
NUTRITIONAL STATUS AND URINARY IODINE LEVELS OF SCHOOL-AGED CHILDREN: IS THERE A CORRELATION?
}

\author{
OKUL YAŞINDAKI ÇOCUKLARIN BESLENME VE ÜRINER IYOT DÜZEYLERI ARASINDA \\ BIR ILIŞKI VAR MI?
}

\author{
Yetunde T OLASINDE ${ }^{1}$ (D), Omotayo O ADESIYUN² (D), Rasaq R OLAOSEBIKAN ${ }^{3}$ (D) Adeola OLASINDE ${ }^{4}$ (D), \\ Olayinka R IBRAHIM ${ }^{5}$ iD, Samuel K ERNEST² (D) \\ 'Bowen University, Department of Paediatrics, Iwo, Nigeria \\ ${ }^{2}$ University of Ilorin, Department of Paediatrics, Ilorin, Nigeria \\ ${ }^{3}$ University of Ilorin Teaching Hospital, Department of Paediatrics, Department of Paediatrics, Ilorin, Nigeria \\ ${ }^{4}$ Kwara State Ministry of Health, Ilorin, Nigeria \\ ${ }^{5}$ Federal Medical Center, Department of Paediatrics, Katsina, Nigeria
}

ORCID IDs of the authors: Y.T.O. 0000-0002-8093-4721; O.O.A. 0000-0002-5127-1914; R.R.O. 0000-0002-3244-2212; A.O. 0000-0002-4354-9016; O.R.I. 0000-0002-2621-6593; S.K.E. 0000-0002-6408-9388

Cite this article as: Olasinde YT, Adesiyun OO, Olaosebikan RR, Olasinde A, Ibrahim OR, Ernest SK. Nutritional status and urinary iodine levels of school-aged children: is there a correlation? J Ist Faculty Med 2021;84(2):221-6. doi: 10.26650/IUITFD.2020.0081

\section{ABSTRACT}

Objective: Impaired physical growth is one of the prolonged effects of deficient iodine, a micronutrient. Thus, this study aimed to determine the relationship between the urinary iodine levels and anthropometric indices in a population of schoolchildren in Ilorin, North-Central Nigeria.

Material and Method: This was a cross-sectional analytical study carried out among primary schoolchildren in Ilorin, North-Central Nigeria. We recruited a total of 492 children aged 6-12 years through a multi-staged systematic sampling technique. Anthropometry was determined using standard methods. We collected urine samples from the pupils and analysed them for iodine in the laboratory using the Sandell-Kolthoff method.

Results: Of the 492 children recruited, 13 (3.2\%) were under weight, 23 (4.7\%) were stunted, 21 (4.3\%) had thinness and obesity was found in 7 (1.5\%). The mean (SD) weight for age $Z$ score (WAZ) was -0.216 (1.089), and height for age $Z$ score (HAZ) was -0.073 (1.286). The mean weight for height $z$ score $(\mathrm{WHZ})$ and weight for age $Z$ score (BAZ) were 1.036 (0.002) and -0.428 (0.976) respectively. A total of $26.5 \%$ of the schoolchildren had mild iodine deficiency, $0.4 \%$ had excess urinary iodine levels and no child had moderate or severe iodine deficiency. There was no relationship between the urinary iodine levels and anthropometric indices (WAZ $p=0.665, \mathrm{HAZ} p=0.978, \mathrm{WHZ} p=0.375$, and BAZ $\mathrm{p}=0.928$ ).

Conclusion: This study showed that there is no relationship be-

\section{ÖZET}

Amaç: Bozulmuş fiziksel büyüme, bir mikrobesin olan iyotun eksikliğinin uzun süreli etkilerinden biridir. Bu çalışma, Kuzey-Orta Nijerya'daki llorin okulundaki bir popülasyonda idrarda iyot düzeyleri ile antropometrik endeksler arasındaki ilişkiyi belirlemeyi amaçlamıştır.

Gereç ve Yöntem: Bu çalışma, Nijerya'nın Kuzey-Orta llorin kentindeki ilkokul çocukları arasında yapılan kesitsel bir analitik çalışmadır. Bu çalışmaya, çok aşamalı sistematik örnekleme tekniği ile 6-12 yaş arası toplam 492 çocuk dahil edildi. Antropometri standart yöntemler kullanılarak belirlendi. Öğrencilerden idrar numuneleri toplandı ve Sandell-Kolthoff yöntemi kullanılarak laboratuarda iyot açısından analiz edildi.

Bulgular: Çalışmaya katılan 492 çocuğun 13'ü $(\% 3,2)$ yaşına göre kilosunun altında, 23'ü $(\% 4,7)$ kısa boylu, 21 'inde $(\% 4,3)$ zayıflık vardı ve 7 'de $(\% 1,5)$ ise obezite saptandı. Yaş Z skoru (WAZ) için ortalama (SD) ağırlık $-0,216(1,089)$ ve yaş Z skoru $(H A Z)$ için yükseklik $-0,073(1,286)$ idi. Boy z skoru $(W H Z)$ ve yaş $Z$ skoru (BAZ) için ortalama ağırlık sırasıyla 1,036 $(0,002)$ ve $-0,428(0,976)$ idi. Okul çocuklarının toplam \%26,5'inde hafif iyot eksikliği, $\% 0,4$ 'ünde aşırı idrar iyot düzeyi saptanırken çocukların hiçbirinde orta veya şiddetli iyot eksikliği yoktu. Üriner iyot düzeyleri ile antropometrik indeksler arasında ilişki yoktu (WAZ $p=0,665$, HAZ $p=0,978, W H Z p=0,375$ ve BAZ $p=0,928$ ).

Sonuç: Bu çalışma beslenme indeksleri ile idrarda iyot düzeyleri

Corresponding author/iletişim kurulacak yazar: yeye1991@yahoo.com

Submitted/Başvuru: 28.06.2020 • Revision Requested/Revizyon Talebi: $18.11 .2020 \bullet$

Last Revision Received/Son Revizyon: 04.12.2020 • Accepted/Kabul: 16.12.2020 • Published Online/Online Yayın: 23.03 .2021 
tween nutritional indices and urinary iodine levels. Hence, nutritional status of schoolchildren may not reflect their iodine level.

Keywords: lodine level, nutritional indices, relationship, hidden hunger, schoolchildren, Nigeria arasında bir ilişki olmadığını göstermiştir. Bu nedenle, okul çocuklarının beslenme durumu iyot seviyelerinin bir yansıması olmayabilir.

Anahtar Kelimeler: lyot düzeyi, beslenme endeksleri, ilişki, gizli açıı, okul çocukları, Nijerya

\section{INTRODUCTION}

Nutritional status reflects the balance or imbalance between the supply and demand of nutritients (1). The nutrition status of an individual is usually assessed through various methods including anthropometry, clinical and biochemical methods (1). Anthropometry is the commonest method of nutritional assessment (1). Anthropometric indices are derivatives of anthropometric measurements; and are expressed in standard deviation units from the reference mean or median value for the age and sex of the population (2).The anthropometric indices include Height-for-age (HAZ), which is an indicator of linear growth and reflects long term nutritional status of a child; Weight-for-height (WHZ), which measures body mass in relation to height or length and describes current nutritional status of the child and Weight-for-age (WAZ), which is a composite index of height-for-age and weightfor-height (1).

Whereas macronutrient deficiencies are easily identified using the anthropometric indices, micronutrient deficiency such as iodine deficiency may not be apparent (hidden hunger) (3). Although severe iodine deficiency causes stunting and mental retardation in-utero, available studies in older children showed conflicting findings (4-10). While previous and out-dated studies showed some form of relationship between goitre and anthropometric indices (6-10), very few studies assessed the relationship between urinary iodine level (a better and more reliable indicator of iodine nutritional status), and anthropometric indices $(5,11)$. Muthayya et al. reported strong associations between stunting, vitamin A deficiency and iron deficiency anaemia but found that iodine deficiency (as measured by the urinary iodine level of schoolchildren) did not correlate with the prevalence of stunting or any of the micronutrient deficiencies (4). However, the review did not explore the relationship between other nutritional indices such as BMI, WAZ and WHZ and urinary iodine level (UIL).

Zimmermann et al., found a $100 \%$ increase in HAZ and WAZ scores over the baseline in a study of iodine-deficient Moroccan children who received iodised salt over a period of 10 months (11). In contrast, an interventional study that involved mildly iodine-deficient South African children reported no significant change in the baseline HAZ or WAZ scores of the subjects after treatment with iodine (11).
In Nigeria, a study in Ibadan, Southwestern Nigeria showed a positive correlation between HAZ and goitre (a measure of iodine status), however, the study did not assess the UIL, a more reliable measure of iodine status (10). A similar study in Southeastern Nigeria also found that stunting and underweight were associated with low UIL (5). However, only 36 of the 330 children studied had their urine tested for iodine.

In view of the various limitations and conflicting results of the earlier studies which compared iodine nutrition and nutritional status, there is a need to explore a possible relationship or otherwise between nutritional status and iodine nutrition using a more robust method of assessing iodine level (UIL) and nutritional indices (HAZ, WHZ, WAZ and BAZ). Hence, this study assessed the urinary iodine level and correlated it with anthropometric indices (HAZ, WHZ, WAZ and BAZ) in a population of schoolchildren in North-Central Nigeria.

\section{MATERIAL AND METHOD}

This was a cross-sectional analytic study carried out between February and May 2016 in primary schools in Ilorin West Local Government Area (LGA). Ilorin west is one of the 16 LGAs in Kwara State, North-Central Nigeria. The recruitment of the subjects was through a multi-staged sampling technique. Using a table of random numbers, we selected 17 (6\%) of the 255 registered primary schools in Ilorin West LGA from the school list obtained from the Kwara State Ministry of Education.

We recruited the number of children in each primary school by dividing the total number of pupils (sample size) by the total number of schools (17), i.e., $415 / 17=25.9$. For easy recruitment of subjects, each primary school had 30 children recruited for the study. In each primary school, the recruitment of the pupils was from each class (basics 1-6). The number of children selected from each class was calculated by dividing the total number of children to be selected from that school by 6 (representing 6 classes from basics 1 to 6 ), i.e., 30/6=5. Where there was more than one class in an arm, we used a simple random balloting to pick a class for the sample population. We obtained relevant information from the parents/caregivers of the schoolchildren through a pretested structure questionnaire.

Anthropometry was taken using standard World Health Organisation (WHO) methods (12); and the anthropomet- 
ric indices were derived according to the WHO classification. Each pupil had his/her weight measured in plain school uniform (extra clothing such as sweaters were removed and the pockets emptied) with a digital bathroom weighing scale (Camry, Model: E B9323H, China) with an accuracy of $100 \mathrm{~g}$. The pupil stood over the centre of the scale with the body weight evenly distributed between both feet. The arms hung freely by the sides of the body with the palms facing the thighs, the head held up, face forward and the weight read to the nearest 100 g. Each pupil had the weighing scale adjusted to zero reading level before the measurement. Each child had his/her height measured in the upright position with his/ her shoes removed; back, shoulders and buttocks perpendicular to the central axis, heels against the footboard, knees together, and arms hanging loosely at the sides and the head in the Frankfurt plane with a stadiometer (Seca Model: 213, USA) with an accuracy of 0.1 $\mathrm{cm}$. Each pupil stood erect with his back touching the vertical backboard of the stadiometer, looking straight ahead and holding his/her breath during the measurement. The moveable headpiece of the stadiometer was brought onto the upper most point on the head with sufficient pressure to compress the hair. The measurement was read off at maximal inspiration.

All the recruited pupils submitted $10 \mathrm{ml}$ of casual (spot) urine sample in clean universal bottles with the lid tightly screwed. We transported the urine samples in icepacks to the University of Ilorin Research Laboratory for analysis using the Sand-ell-Kolthoff method. In brief, the Sandell-Kolthoff method measured the rate of colour disappearance of ceric ammonium sulphate in urine digested with ammonium persulfate (Sand-ell-Kolthoff reaction); the rate of colour disappearance as measured by a colour spectrophotometer determined the iodine content of the urine sample.

\section{Ethical consideration}

The Ethics and Research Committee of the University of Ilorin Teaching Hospital gave ethical clearance for this study. The parents/caregivers signed an informed consent, while children ten years and above signed the assent form. Kwara State Ministry of Education also approved the study. Furthermore, the Head Teachers of the selected schools gave permission for the study.

\section{Data analysis}

We analysed the data collected on the study proforma using the IBM-Statistical Package for Social Sciences $(\text { SPSS })^{T m}$ version 20.0 for windows. We used Anthroplus ${ }^{\circledR}$, (WHO software for analysing anthropometric parameters) to calculate body mass index (BMI)-for-age, heightfor-age, weight-for-age and weight-for-height Z scores based on the WHO Growth Reference dataset. Urinary iodine level was not normally distributed and was sum- marised as the median value with interquartile ranges (IQR). Kruskal Wallis test was used to compare the median values of the UIL across the different strata of nutritional indices, while Pearson correlation test was used to assess the correlation between the anthropometric indices and UIL. We further evaluated the relationship between anthropometric indices and UIL using Odds ratio with $95 \%$ confidence interval and the level of significance was set at $p<0.05$.

\section{RESULTS}

Out of five hundred and ten pupils recruited into the study, 492 had complete data and giving a response rate of $96 \%$ from the seventeen primary schools in Ilorin, Kwara State. The mean \pm standard deviation age of the pupils was $8.5 \pm 1.8$ years. Two hundred and forty-two (49.3\%) of the children were males and 250 (50.7\%) were females as shown Table 1. The overt clinical features of

Table 1: Socio-demographic, physical examination findings and urinary iodine level of schoolchildren

\begin{tabular}{|c|c|c|}
\hline Variable & $\begin{array}{l}\text { Frequency } \\
(n=492)\end{array}$ & $\%$ \\
\hline \multicolumn{3}{|l|}{ Age (years) } \\
\hline 6 & 71 & 14.5 \\
\hline 7 & 91 & 18.5 \\
\hline 8 & 79 & 16.0 \\
\hline 9 & 89 & 18.1 \\
\hline 10 & 82 & 16.6 \\
\hline 11 & 51 & 10.3 \\
\hline 12 & 29 & 5.9 \\
\hline \multicolumn{3}{|l|}{ Sex } \\
\hline Male & 242 & 49.3 \\
\hline Female & 250 & 50.7 \\
\hline \multicolumn{3}{|l|}{ Social class } \\
\hline High (class I \& II) & 282 & 57.3 \\
\hline Middle (class III) & 139 & 28.2 \\
\hline Low (class IV \& V) & 72 & 14.5 \\
\hline \multicolumn{3}{|c|}{ Examination findings $(n=12)$} \\
\hline Nail changes & 9 & 75.0 \\
\hline Skin changes & 1 & 8.3 \\
\hline Fluffy hair & 1 & 8.3 \\
\hline Angular stomatitis & 1 & 8.3 \\
\hline Goitre & 0 & 0.0 \\
\hline \multicolumn{3}{|l|}{ lodine level } \\
\hline Mild deficiency & 130 & 26.5 \\
\hline Normal & 338 & 68.7 \\
\hline Above normal & 22 & 4.4 \\
\hline Excess urinary iodine & 2 & 0.4 \\
\hline
\end{tabular}

Severe iodine deficiency: UIL $=0-19 \mu \mathrm{g} / \mathrm{L}$, Moderate iodine deficiency: UIL=20-49 $\mu \mathrm{g} / \mathrm{L}$, Mild deficiency: $U \mathrm{IL}=50-99 \mu \mathrm{g} / \mathrm{L}$, Normal iodine level: UIL=100-199 $\mu \mathrm{g} / \mathrm{L}$, Above normal iodine level:UIL=200-299 $\mu \mathrm{g} / \mathrm{L}$, Excess urinary iodine: $U \mathrm{IL}=>300 \mu \mathrm{g} / \mathrm{L}$ 
malnutrition namely fluffy hair, angular stomatitis, nail fissuring and skin changes were present in $12(1.0 \%)$ of the pupils. No child had goitre $(0 / 492,0 \%)$. One hundred and thirty $(25.6 \%)$ of the subjects had mild iodine deficiency. None of the pupils had moderate or severe iodine deficiency as shown in Table 1.

Using the $\mathrm{WHO}$ classification, underweight was found in $13(3.2 \%)$, stunting in $23(4.7 \%)$, thinness in $21(4.3 \%)$ and obesity in $7(1.5 \%)$ of the pupils. The mean (SD) weight for age $Z$ score (WAZ) was -0.216 (1.089) and height for age $Z$ score (HAZ) was -0.073 (1.286). The weight for height $z$ score (WHZ) and weight for age $Z$ score (BAZ) were 1.036 (0.002) and $-0.428(0.976)$ respectively. The other details are shown in Table 2.

The median (IOR) urinary iodine level of the study population was 117.2 (99.6-148.6) $\mu \mathrm{g} / \mathrm{L}$. No significant difference was found when the median UIL was compared across each nutritional group as shown in Table 3 ( $p>0.05)$. Using the Pearson correlation test, there

Table 2: Anthropometric parameters of the school children

\begin{tabular}{|c|c|c|}
\hline Variable & $\begin{array}{l}\text { Frequency } \\
(n=492)\end{array}$ & $\%$ \\
\hline \multicolumn{3}{|c|}{ Weight for age $Z$ - score $(n=412)^{*}$} \\
\hline$<-2$ & 13 & 3.2 \\
\hline$-2-+2$ & 388 & 94.2 \\
\hline$>+2$ & 11 & 2.6 \\
\hline Mean (SD) & $-0.216(1.089)$ & \\
\hline \multicolumn{3}{|c|}{ Height for age Z- score } \\
\hline$<-2$ & 23 & 4.7 \\
\hline$-2-+2$ & 439 & 89.2 \\
\hline$>+2$ & 30 & 6.1 \\
\hline Mean (SD) & $-0.073(1.286)$ & \\
\hline \multicolumn{3}{|c|}{ Weight for height Z-score } \\
\hline$<-2$ & 21 & 4.3 \\
\hline$-2-+2$ & 443 & 90.1 \\
\hline$>+2$ & 28 & 5.6 \\
\hline Mean (SD) & $1.036(0.002)$ & \\
\hline \multicolumn{3}{|c|}{ BMI for age Z- score } \\
\hline$<-2$ & 21 & 4.3 \\
\hline$-2-+2$ & 464 & 94.2 \\
\hline$>+2$ & 7 & 1.5 \\
\hline Mean (SD) & $-0.428(0.976)$ & \\
\hline
\end{tabular}

*Weight for age $z$ score not available for children $>11$ years
Table 3: Relationship between the urinary iodine level (UIL) and nutritional status of the schoolchildren

\begin{tabular}{|c|c|c|c|c|c|}
\hline \multicolumn{6}{|c|}{ UIL } \\
\hline Variable & $n$ & Median & $\begin{array}{l}\text { Inter- } \\
\text { quartile } \\
\text { range }\end{array}$ & K & $\begin{array}{c}\mathrm{p} \\
\text { value }\end{array}$ \\
\hline \multicolumn{6}{|l|}{ WAZ* } \\
\hline$<-2$ & 13 & 132.7 & $116.1-152.5$ & 2.600 & 0.273 \\
\hline$-2-+2$ & 388 & 117.2 & 101.4-149.3 & & \\
\hline$>+2$ & 11 & 115.6 & $94.2-152.4$ & & \\
\hline \multicolumn{6}{|l|}{ HAZ } \\
\hline$<-2$ & 23 & 112.2 & $99.5-134.4$ & 1.485 & 0.476 \\
\hline$-2-+2$ & 439 & 117.2 & $99.6-149.2$ & & \\
\hline$>+2$ & 30 & 110.8 & $91.5-148.3$ & & \\
\hline \multicolumn{6}{|l|}{ WHZ } \\
\hline$<-2$ & 21 & 112.2 & 100.3-136.9 & 1.310 & 0.519 \\
\hline$-2-+2$ & 443 & 117.2 & $99.6-149.2$ & & \\
\hline$>+2$ & 28 & 110.8 & 88.8-144.4 & & \\
\hline \multicolumn{6}{|l|}{ BAZ } \\
\hline$<-2$ & 21 & 137.1 & 110.4-152.6 & 2.481 & 0.289 \\
\hline$-2-+2$ & 464 & 117.2 & $99.6-148.6$ & & \\
\hline \multirow[t]{2}{*}{$>+2$} & 7 & 115.6 & $87.2-135.4$ & & \\
\hline & & & $r$ & & $p$ \\
\hline WAZ* & 412 & & -0.021 & & 0.665 \\
\hline HAZ & 492 & & 0.001 & & 0.978 \\
\hline WHZ & 492 & & -0.040 & & 0.375 \\
\hline BAZ & 492 & & 0.004 & & 0.928 \\
\hline
\end{tabular}

*Weight for age z score(WAZ) not available for children >11years K:Kruskal Wallis; r:Pearson correlation coefficient; WAZ:weight-forage Z score; HAZ:height-for-age Z score; WHZ:Weight-for-height Z-score; BAZ:BMI-for-age Z score

was no correlation between the nutritional indices and UIL. This is as shown in Table 3. The odds of a pupil being stunted and iodine deficient was 1.029, although not statistically significant, $(\mathrm{Cl}=0.393-2.694, \mathrm{p}=0.954)$ as shown in Table 4.

\section{DISCUSSION}

Our study found no relationship between the iodine nutrition and nutritional status of children which contrasts with the previous studies in Nigeria $(5,10)$. This study, however, supports the findings of Mutthaya in a global review of the prevalence of micronutrient deficiencies (4); that the global prevalence of iodine deficiency did not correlate significantly with the prevalence of stunting. The differences in our findings compared to the earlier works in 
Table 4: Relationship between iodine status and anthropometric indices of schoolchildren

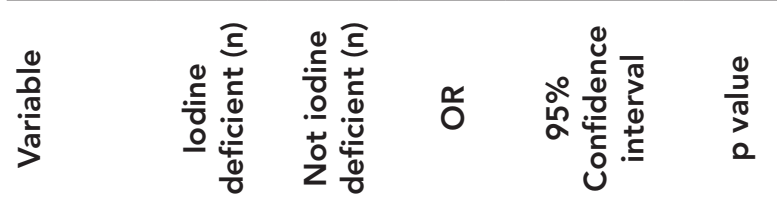

\begin{tabular}{|c|c|c|c|c|c|}
\hline \multicolumn{6}{|l|}{ WAZ } \\
\hline$<-2$ & 0 & 93 & 0.110 & $0.007-1.861$ & 0.126 \\
\hline$>+2$ & 4 & 7 & 1.696 & $0.486-0.592$ & 0.408 \\
\hline-2 to $+2^{\star}$ & 13 & 276 & & & \\
\hline \multicolumn{6}{|l|}{ HAZ } \\
\hline$<-2$ & 6 & 16 & 1.016 & $0.388-2.660$ & 0.975 \\
\hline$>+2$ & 11 & 17 & 1.752 & $0.796-3.855$ & 0.163 \\
\hline-2 to $+2^{*}$ & 113 & 306 & & & \\
\hline \multicolumn{6}{|l|}{ WHZ } \\
\hline$<-2$ & 5 & 15 & 0.890 & $0.316-2.504$ & 0.825 \\
\hline$>+2$ & 10 & 17 & 1.570 & $0.699-3.530$ & 0.275 \\
\hline-2 to $+2^{\star}$ & 115 & 307 & & & \\
\hline \multicolumn{6}{|l|}{ BAZ } \\
\hline$<-2$ & 4 & 15 & 0.692 & $0.225-2.125$ & 0.520 \\
\hline$>+2$ & 3 & 4 & 1.945 & $0.429-8.817$ & 0.388 \\
\hline-2 to $+2^{\star}$ & 123 & 319 & & & \\
\hline
\end{tabular}

*Reference; OR:odds ratio; WAZ:weight-for-age Z score;

HAZ:height-for-age Z score; WHZ:Weight-for-height Z-score; BAZ:BMI-for-age Z score

Nigeria may be related to the difference in methodology between our study and the previous Nigerian studies. The study in Enugu, Nigeria sampled the urine of only a small proportion of the studied children (36 children compared with 492 children in our study). Furthermore, the present study assessed the urinary iodine level while the study in Ibadan assessed the goitre rate. Goitre rate tends to reflect longstanding iodine deficiency compared with UIL, which is an indicator of the current iodine status of an individual (13).

Also, we did not find any difference in the median UIL of underweight pupils and those with normal weightfor-age ratio. Similarly, the median UIL was comparable among the stunted pupils and those without stunting. These findings are in contrast to earlier findings in Morocco where iodine repletion significantly increased WAZ and HAZ scores (11). The inability to find any differences in this present study may be because the present study was not an interventional study and rather relied on information on the ongoing iodine fortification of salt as part of the country's nutritional policy (14).
The present study also showed no correlation between UIL and the nutritional indices (WAZ, HAZ, WHZ, and $B A Z$ ). This finding is similar to observation among Senegalese pupils where there was no association between micronutrient deficiency and stunting/thinness (15). This negates the findings of Nwamarah and Okeke who found a positive correlation between UIL and HAZ (5). The reason for this difference is not clear, but may be because this present study did not record any severe iodine deficiency unlike Nwamarah et al. who recorded a high prevalence (58\%) of severe iodine deficiency (5). Furthermore, there was no association between children that were iodine deficient and those that had low anthropometric indices. This may be because most (90\%) of the pupils we studied had normal nutritional indices.

Our study showed that children that have mild iodine deficiency may have normal anthropometric indices as observed in the study. This observation supports the fact that micronutrient deficiency may not be apparent from nutritional indices and hence the term hidden hunger has been coined. This term implies that the signs are not always visible in those affected by it. Globally, about two billion people reportedly suffer from hidden hunger, which is a chronic deficiency of micronutrients (3).

Limitations: This was a cross-sectional study rather than a longitudinal study that would show the iodine status of the schoolchildren over time.

Ethics Committee Approval: This study was approved from the University of Ilorin Teaching Hospital Ethics Committee (Date:19.11.2015, No:PAN/1477).

Informed Consent: Written consent was obtained from the participants.

Peer Review: Externally peer-reviewed.

Author Contributions: Conception/Design of Study- Y.T.O., O.O.A., R.R.O., S.K.E.; Drafting Manuscript- O.R.I., Y.T.O., O.O.A., R.R.O., A.O., S.K.E.; Final Approval and AccountabilityY.T.O, O.O.A., R.R.O., A.O., O.R.I., S.K.E

Conflict of Interest: Authors declared no conflict of interest.

Financial Disclosure: Authors declared no financial support.

Etik Komite Onayı: Bu çalışma için etik komite onayı Ilorin Üniversitesi Eğitim Hastanesi Etik Kurulu'ndan alınmıştır (Tarih:19.11.2015, Sayı:PAN/1477).

Bilgilendirilmiş Onam: Katılımcılardan bilgilendirilmiş onam alınmıştır.

Hakem Değerlendirmesi: Dış bağımsız.

Yazar Katkıları: Çalışma Konsepti/Tasarım- Y.T.O., O.O.A., R.R.O., S.K.E.; Yazı Taslağı- O.R.I., Y.T.O., O.O.A., R.R.O., A.O., 
S.K.E.; Son Onay ve Sorumluluk- Y.T.O, O.O.A., R.R.O., A.O., O.R.I., S.K.E.

Çıkar Çatışması: Yazarlar çıkar çatışması beyan etmemişlerdir.

Finansal Destek: Yazarlar finansal destek beyan etmemişlerdir.

\section{REFERENCES}

1 Puntis JWL. Clinical methods and anthropometry. In: Koletzko B, Bhatia J, Bhutta ZA, Cooper P, Makrides M, Uauy R, et al. (eds). Pediatric Nutrition in Practice. Karger: Munich, Germany, 2015, pp 6-13.

2 World Health Organisation. Global Database on Child Growth and Malnutrition: Child growth and their indicators. Geneva, 2016.

3 Godecke T, Stein AJ, Qaim M. The global burden of chronic and hidden hunger: Trends and determinants. Glob Food Sec 2018;17:21-9. [CrossRef]

4 Muthayya S, Rah JH, Sugimoto JD, Roos FF, Kraemer K, Black RE. The global hidden hunger indices and maps: an advocacy tool for action. PLoS One 2013;8(6):e67860. [CrossRef]

5 Nwamarah JU, Okeke EC. A pilot study of iodine and anthropometric status of primary school children in Obukpa, a rural Nigerian community. J Public Heal Epidemiol 2012;4(9):246-52. [CrossRef]

6 Ersoy B, Gunes H, Gunay T, Yilmaz O, Kasirga E, Egemen A. Interaction of two public health problems in Turkish schoolchildren: nutritional deficiencies and goitre. Public Health Nutr 2006;9:1001-6. [CrossRef]

7 Koutras DA, Christakis G, Trichopoulos D, DakouVoutetaki A, Kyriakopoulos V, Fontanares P, et al. Endemic goiter in Greece: nutritional status, growth, and skeletal development of goitrous and nongoitrous populations. Am J Clin Nutr 1973;26(12):1360-8. [CrossRef]
8 Osman A, Khalid B, Tan T, Wu L, Ng M. Protein energy malnutrition, thyroid hormones and goitre among Malaysian Aborigines and Malays. Asia Pac J Clin Nutr 1992;1(1):13-20.

9 Brahmbhatt SR, Brahmbhatt RM, Boyages SC. Impact of protein energy malnutrition on thyroid size in an iodine deficient population of Gujarat (India): is it an aetiological factor for goiter? Eur J Endocrinol 2001;145(1):11-7. [CrossRef]

10 Sanusi RA, Ekerette NN. Nutrition and goiter status of primary school children in Ibadan, Nigeria. African J Biomed Res 2009;12(1):37-41.

11 Zimmermann MB, Jooste PL, Mabapa NS, Mbhenyane $X$, Schoeman S, Biebinger R, et al. Treatment of iodine deficiency in school-age children increases insulinlike growth factor (IGF)-I and IGF binding protein-3 concentrations and improves somatic growth. J Clin Endocrinol Metab 2007;92(2):437-42. [CrossRef]

12 World Health Organisation. WHO Child Growth Standards: length/height-for-age, weight-for-age, weight-for-length, weight-for-height and body mass index-for-age: methods and development. Geneva, 2006.

$13 \mathrm{WHO}$. Urinary iodine concentrations for determining iodine status in populations. Geneva, 2013.

14 Akunyili DN. Achieving and sustaining universal salt iodization(USI): doing it well through regulation and enforcement. Lessons learned from USI in Nigeria. SCN NEWS 2007;35:43-7.

15 Fiorentino M, Bastard G, Sembène M, Fortin S, Traissac $P$, Landais $E$, et al. Anthropometric and micronutrient status of school-children in an urban West Africa setting: A cross-sectional study in Dakar (Senegal). PLoS One 2013;8(12):e84328. [CrossRef] 